\title{
ANALISIS RASIO LIKUIDITAS UNTUK MENILAI TINGKAT KESEHATAN LAPORAN KEUANGAN PT. HARAPAN GUNA SEJAHTERA MEDAN
}

\author{
Akim Manaor Hara Pardede ${ }^{1}$, Budi Serasi Ginting, S.Kom., M.Kom. ${ }^{2}$ \\ Program Studi Teknik Informatika, STMIK Kaputama \\ Jln.Veteran No.4A-9A, Binjai, Indonesia
}

\begin{abstract}
Abstrak
Seiringi perkembangan industri meningkat begitu cepat, untuk meningkatkan operasionalnya pada PT. Harapan Guna Sejahtera Medan melakukan analisis rasio untuk menilai tingkat kesehatan laporan keuangan guna mengetahui tingkat kesehatan laporan keuangan. Serta mengidentifikasi masalah yang ada agar dapat dilakukan manajemen operasi yang lebih baik sehingga mengatasi masalah yang dihadapi.

Adapun masalah yang dihadapi pada PT. Harapan Guna Sejahtera Medan di mana terdapatnya ketidak optimalanya laporan keuangan, kekurangan analisa tentang laporan keuangan sehingga menimbulkan terhambatnya proses pelaporan keuanganyang dapat menghambat proses keuangan.

Sehubungan hal tersebut maka penelitian menerapkan analisa rasio yang menjadi solusi dapat digunakan untuk menilai tingkat kesehatan laporan keuangan, dengan hasil yang diharapkan dapat memberikan hasil yang maksimal.

Adapun kegunaan penelitian ini adalah dapat bermanfaat baik secara teorotis maupun secara praktis sebagai bahan masukan khususnya mengenai penerapan metode analisa rasio agar perusahaan dapat mengetahui bahwa dengan metode tersebut laporan keuangan dapatdioptimalkan, sehingga akan memperlancar proses pelaporan keuangan dan meningkatkan laba yang akan diperoleh perusahaan.
\end{abstract}

Kata Kunci : Analisa, Rasio, Tingkat Kesehatan Laporan Keuangan, Kinerja perusahaan.

\section{PENDAHULUAN \\ 1.1 Latar Belakang}

Pertumbuhan pembangunan di Indonesia dalam masa pasca krisis ekonomi dapat dikatakan mengalami kenaikan walaupun dalam kategori lambat, pada proyek-proyek di bidang konstruksi menjadi salah satu bidang usaha yang menjadi ajang kompetisi banyak kontraktor. Hal ini akan mempengaruhi langkah kontraktor dalam menentukan apa yang harus dilakukan, untuk mampu bertahan kontraktor dituntut secara aktif mendapatkan pekerjaan dengan berperilaku profesional, antara lain dengan mengutamakan kualitas, ketepatan waktu dan efisensi biaya. Sebagai langkah awal kontraktor untuk mendapatkan proyek adalah dengan mengikuti proses tender (penawaran), karena tanpa mengikuti tahapan ini kontraktor tidak akan bisa melakukan proses produksi.

PT Harapan Guna Sejahtera Medan dapat berkembang dengan cepat apabila laporan keuangan yang dimiliki oleh perusahaan sesuai dengan sistem akuntansi, untuk memberikan gambaran mengenai perkembangan usaha suatu perusahaan. Perkembangan perusahaan ini sangat penting untuk diketahui oleh berbagai pihak sebagai dasar untuk menggambil keputusan.

$$
\text { Laporan keuangan yang }
$$
menyajikan informasi tentang kondisi keuangan suatu perusahaan dari hasil usahanya akan menjadi semakin berarti jika dianalisis lebih lanjut. Sifat dan analisis yang dilakukan tergantung dari kepentingan pihak pemakai. Dengan penganalisisan laporan keuanagn yang ditujukan terhadap analisis dan pos-pos neraca dan laba rugi dapat diperoleh informasi mengenai perkembanagan hasil perusahaan pada suatu periode tertentu.

Berdasarkan laporan keuangan 3 tahun terakhir yang digambarkan oleh tabel diatas dapat dilihat bahwa perusahaan mengalami peningkatan jumlah aktiva namun secara akun per akun perusahaan mengalami naik turun nilai masing-masing akun hal ini menjadi dasar bagi saya untuk melakukan analisis laporan keuangan guna menilai kinerja perusahaan serta kelayakan dan kelangsungan berdasarkan suatu analisa laporan keuangan.

Berdasarkan penelitian Hayadi Sarjono, ST, MM, (2005) yang berjudul "Analisis laporan keuangan sebagai alat predeksi kemungkinan kebangkrutan dengan model diskriminan altman pada sepuluh 
perusahaan properti dibursa efek jakarta “ menyatakan Analisis laporan keuangan merupakan alat yang sangat penting untuk mengetahui posisi keuangan perusahaan serta hasil-hasil yang telah dicapai sehubungan dengan pemilihan strategi perusahaan yang telah dilaksanakan dan Analisis rasio keuangan merupakan suatu alternatif untuk menguji apakah informasi keuangan yang dihasilkan oleh akuntansi keuangan bermanfaat untuk melakukan klasifikasi atau prediksi kebangkrutan perusahaan.

Melihat peranan penting dari analisis laporan keuangan sebagai masukan dari pihak-pihak berkepentingan untuk menggambil keputusan berkenan dengan kegiatan pengelolaan perusahaan, maka penulis tertarik untuk menganalisis laporan keuangan PT. Harapan Guna Sejahtera.

\subsection{Identifikasi Masalah}

Dalam penelitian ini didapatkan aspek yang menjadi identifikasi masalah dalam menganalisis laporan keuangan antara lain :

1. Apakah rasio likuiditas perusahaan sudah menunjukkan kondisi perusahaan yang baik?

2. Apakah analisis rasio likuiditas pada PT Harapan Guna Sejahtera dijadikan alat ukur kinerja keuangan perusahaan?

\subsection{Batasan Masalah}

Melihat permasalahan yang dihadapi dan keterbatasan kemampuan peneliti, maka peneliti melakukan batasan masalah, yaitu :

1. Analisis laporan keuangan PT. Harapan Guna Sejahtera Medan.

2. Analisis laporan keuangan dengan menggunakan rasio likuiditas.

3. Program yang digunakan di dalam melakukan analisis laporan keuangan pada PT. Harapan Guna Sejahtera Medan menggunakan program Visual Basic net (VB net).

\subsection{Rumusan Masalah}

Laporan keuangan merupakan suatu faktor yang penting dalam pengambilan keputusan yang dilakukan oleh manajemen. Melihat pentingnya pengambilan keputusan yang dilakukan manajemen, maka penulis merumuskan masalah yaitu : “ Apakah analisis rasio likuiditas pada PT. Harapan Guna Sejahtera Medan sudah menunjukkan kondisi keuangan perusahaan yang baik?"

\subsection{Tujuan Penelitian}

Adapun tujuan dari penelitian yang dilakukan adalah:

1. Untuk mengetahui hasil analisis laporan keuangan PT. Harapan Guna Sejahtera Medan.

2. Untuk mengetahui keadaan keuangan PT.

Harapan Guna Sejatera Medan.

3. Untuk mengetahui hambatan-hambatan di bidang keuangan pada PT. Harapan Guna Sejahtera Medan.

\subsection{Manfaat Penelitian}

Adapun manfaat dari penelitian yang dilakukan adalah sebagai berikut :

1. Bagi Perusahaan

Dapat dijadikan bahan masukan mengenai manfaat penggunaan analisis laporan keuangan

2. Bagi Penulis

Dapat penulis pergunakan sebagai latihan dan penerapan ilmu pengetahuan yang penulis terima di bangku perkulihan, serta pengalaman tentang cara menganalisis laporan keuangan yang sebenarnya.

3. Bagi Mahasiswa

Dapat dipergunakan sebagai bahan perbandingan antara teori dengan praktek, juga dapat dimanfaatkan sebagai bahan penelitian berikutnya.

\section{LANDASAN TEORI}

\subsection{Pengertian Analisis}

Rasio dalam analisis keuangan adalah suatu angka yang menunjukkan hubungan antara suatu unsur dengan unsur yang lainnya dalam laporan keuangan. Hubungan antara unsur-unsur laporan keuangan tersebut dinyatakan dalam bentuk matematis yang sederhana. Secara individual rasio itu dapat di nilai jika dibandingkan dengan suatu standart rasio yang layak dijadikan dasar pembanding.

Menurut Satradipoera (2004:173), disebutkan bahwa "Analisis rasio adalah pangkajian yang dipergunakan oleh penyedia dan pengguna laporan keuangan (dalam hal ini, bisnis perbankan) untuk menilai kekuatan dan kelemahan keuangan dan kecenderungan operasi sebuah perusahaan. Analisis rasio akan menyebabkan pengukuran relative terhadap kondisi dan kinerja perusahaan yang akan mengajukan aplikasi kredit kepada sebuah bisnis perbankan".

Berdasarkan uraian di atas penulis dapat mendefinisikan bahwa analisis mempunyai tujuan sebagai berikut : 
1. Menjelaskan penerapan proses proyeksi dalam penilaian efek ekuitas.

2. Menjelaskan proses proyeksi laporan laba rugi, neraca, dan laporan arus kas.

3. Menjelaskan relevansi audit dan laporan audit (opini) atas analisis laporan keuangan.

4. Menjelaskan tentang penyusunan ulang (recasting) serta penyesuaian laba dan komponen laba untuk tujuan analisis.

5. Menguraikan penilaian ekuitas (equity valuation) dan relevannya pada analisis keuangan.

6. Menganalisis kekuatan laba (earning power) dan kegunaannya untuk peramalan dan penilaian.

7. Menjelaskan peramalan laba, mekanisme, dan efektivttasnya dalam menilai kinerja perusahaan.

8. Menganalisis laporan intern dan mempertimbangkan manfaatnya dalam memonitor dan merevlesi estimasi laba.

\section{Pengertian Laporan Keuangan}

Laporan keuangan merupakan hasil akhir dari suatu proses pencatatan, yang merupakan ringkasan dari transaksitransaksi keuangan yang terjadi selama tahun buku yang bersangkutan (Najmudin, $2011: 63$ )

Pengertian laporan keuangan menurut Standar Akuntansi Keuangan (SAK) :

"Laporan keuangan merupakan bagian dari proses pelaporan keuangan. Laporan keuangan yang lengkap biasanya meliputi laba-rugi, laporan arus kas, neraca, laporan perubahan posisi keuangan (yang dapat disajikan dalam berbagai cara seperti sebagai laporan arus kas, atau laporan arus dana), catatan juga termasuk skedul dan informasi tambahan yang berkaitan dengan laporan tersebut, misal informasi keuangan segmen industri dan geografis serta pengungkapan pengaruh perubahan harga".

Dari pengertian di atas laporan keuangan dibuat sebagai bagian dari proses pelaporan keuangan yang lengkap, dengan tujuan untuk mempertanggung jawabkan tugas-tugas yang dibebankan kepada manajemen.

Penyusunan laporan keuangan disiapkan mulai dari berbagai sumber data, terdiri dari faktur-faktur, bon-bon, nota kredit, salinan faktur penjualan, laporan bank dan sebagainya. Data yang asli bukan saja digunakan untuk mengisi buku perkiraan, tetapi dapat juga dipakai untuk membuktikan keabsahan transaksi (Najmudin, 2011: 65).

Laporan keuangan pada dasarnya adalah hasil dan proses akuntansi yang dapat digunakan untuk alat komunikasi antara data keuangan atau aktivitas perusahaan dengan pihak-pihak yang mempunyai kepentingan dengan data keuangan suatu perusahaan. Pihak-pihak yang berkepentingan tersebut menurut (Najmudin, $2011:$ 68) adalah :

1. Pemilik Perusahaan

Pihak ini sangat berkepentingan untuk mengetahui suatu laporan keuangan perusahaannya, karena dengan melihat laporan keuangannya maka pemilik dapat menilai apakah dia benar-benar dapat menjalankan tugasnya sebagai seorang pemimpin. Kesuksesan ini biasanya dinilai dari laba yang diperoleh oleh perusahaan.

2. Manajer Perusahaan

Setelah mengetahui laporan keuangan, maka manajer dapat menilai kebijakankebijakan yang telah dijalankannya, dan jika ada kekurangan bias untuk menyusun sistem kebijaksanaan yang lebih baik lagi.

3. Investor

Laporan keuangan berguna dalam hal keperluan mereka untuk menanamkan modal mereka ke suatu perusahaan.

4. Kreditur dan Banker

Berhubungan dengan pemberian kredit bagi suatu perusahaan. Dengan melihat laporan keuangan mereka bisa mengambil keputusan apakah akan menyetujui atau bahkan menolak pemberian kredit kepada perusahaan yang bersangkutan.

5. Pemerintah

Pemerintah memerlukan laporan keuangan untuk menentukan berapa besarnya pajak yang harus dibayarkan oleh pemilik perusahaan.

Berdasarkan uraian di atas penulis dapat mendefinisikan bahwa laporan keuangan merupakan hasil dari proses akuntansi yang dapat digunakan sebagai alat untuk berkomunikasi antara data keuangan atau aktivitas suatu perusahaan dengan pihak-pihak yang berkepentingan dengan data atau aktivitas perusahaan tersebut.

\subsubsection{Tujuan Laporan Keuangan}

Laporan keuangan beserta pengungkapannya dibuat perusahaan dengan tujuan memberikan informasi yang berguna untuk pengambilan keputusan-keputusan 
investasi dan pendanaan, seperti yang dinyatakan dalam SFAC No. I bahwa laporan keuangan harus memberikan informasi :

1. untuk keputusan investasi dan kredit.

2. mengenai jumlah dan timing arus kas.

3. mengenai aktiva dan kewajiban.

4. mengenai kinerja perusahaan.

5. mengenai sumber dan penggunaan kas.

6. penjelas dan interpretif.

7. untuk menilai stewardship.

Ketujuh tujuan ini terangkum dengan disajikannya laporan laba rugi, neraca, laporan arus kas dan pengungkapan laporan keuangan.

Menurut PSAK No. I :

Tujuan laporan keuangan untuk tujuan umum adalah untuk memberikan informasi tentang posisi keuangan, kinerja dan arus kas, perusahaan yang bermanfaat bagi sebagian besar kalangan pengguna laporan dalam jangka membuat keputusan keputusan ekonomi sertam menunjukkan pertanggung jawaban (stewardship) manajemen atas penggunaan sumbersumber daya yang dipercayakan kepada mereka dalam rangka mencapai tujuan tersebut, suatu laporan keuangan menyajikan informasi mengenai perusahaan yang meliput :

1) aktiva

2) kewajiban

3) ekuitas

4) pendapatan, beban termasuk keuntungan dan kerugian

5) arus kas.

\subsubsection{Komponen Laporan Keuangan}

Laporan keuangan yang lengkap terdiri dari komponen-komponen berikut ini:

1) Neraca

2) Laporan laba rugi

3) Laporan perubahan ekuitas

4) Laporan arus kas

5) Catatan atas lapoaran keuangan.

\subsubsection{Neraca}

Neraca perusahaan disajikan sedemikian rupa yang menggambarkan posisi keuangan suatu perusahaan pada saat tertentu makzudnya adalatt menunjukkan keadaan keuangan pada tanggal tertentu biasanya pada saat tutup buku. Neraca minimal mencakup pos-pos berikut (IAI, 2004) :

1) Aktiva berwujud,

2) Aktiva tidak benrujud,

3) Aktivakeuangan,

4) Investasi yang diperlakukan menggunakan metode ekuitas,
5) Persediaan,

6) Piutang usaha dan piutang lainnya,

7) Kas dan setarakas,

8) Hutang usaha dan hutang lainnya,

9) Kewajiban Yang diestimasi,

10) Kewajiban berbunga jangka panjang,

11) Hak minoritas,

12) Modal saham dan pos ekuitas lainnya.

\subsubsection{Laporan Laba Rugi}

Laporan laba rugi merupakan suatu laporan yang sistematis mengenai penghasilan, biaya rugi laba yang diperoleh oleh suatu perusahaan selama periode tertentu (Munawir, 2000:26). Tujuan pokok laporan laba rugi adalah melaporkan kemampuan riil perusahaan dalam menghasilkan keuntungan. Laporan laba rugi perusahan disajikan sedemikian rupa yang menonjolkan berbagai unsur kinerja keuangan yang diperlukan bagi penyajian secara wajar. Laporan laba rugi minimal mencakup pos -pos berikut (IAI, 2004:) :

1) Pendapatan,

2) Laba rugi usaha,

3) Beban pinjaman,

4) Bagian dari laba atau rugi perusahaan

5) Beban pajak,

6) Laba atau rugi dari aktivitas normal perusahaan,

7) Pos luar biasa,

8) Hak minoritas,

9) Laba atau rugi bersih untuk periode berjalan.

\subsubsection{Laporan Perubahan Ekuitas}

$\begin{array}{rlr}\text { Laporan } & \text { perubahan } & \text { ekuitas } \\ \text { menggambarkan } & \text { peningkatan } & \text { atau }\end{array}$ penurunan aktiva bersih atau kekayaan selarna periode yang bersangkutrn. Perusahaan harus menyajikan laporan perubahan ekuitas sebagai komponen utama laporan keuangan, yang menunjukan (IAI, 2004) :

1) Laba atau rugi bersih perode yang bersangkutan

2) Setiap pos pendapatan dan beban, keuntungan atau kerugian beserta jumlahnya yang berdasarkan PSAK terkait diakui secara langsung dalam ekuitas

3) Pengaruh kumulatif dari perubahan kebijakan akuntansi dan perbaikan terhadap kesalahan mendasar sebagaimana diatur dalam PSAK terkait

4) Transaksi modal dengan pemilik dan distribusi kepada pemilik

5) Saldo akumulasi laba atau rugi pada awal dan akhir periode serta perubahan 
6) Rekonsiliasi antar nilai tercatat dari masing -masing jenis modal saham, agio dan cadangan pada awal dan akhir periode yang mengungkapkan secara terpisah setlap perubahan.

Laporan perubahan ekuitas, kecuali untuk perubahan yang berasal dari transaksi dengan pemegang saham seperti setoran modal dan pembayaran dividen, menggambarkan jumlah keuntungan dan kerugian yang berasal dari kegiatan perusahaan selama periode yang bersangkutan.

\subsubsection{Laporan arus kas}

Laporan arus kas dapat memberikan informasi yang memungkinkan para pemakai untuk mengevaluasi perubahan dalam aktiva bersih perusahaan, struktur keuangan (termasuk likuiditas dan solvabilitas) dan kemampuan untuk mempengaruhi jurnlah serta waktu arus kas dalarn rangka adaptasi dengan perubahan keadaan dan peluang (AI, 2004). Informasi arus kas berguna untuk menilai kemampuan perusahaan dalam menghasilkan kas dan setara kas dan memungkinkan para pemakai mengembangkan model untuk menilai dan membandingkan nilai sekarang dari arus kas masa depan (future cash flow) dari berbagai perusahaan.

\subsubsection{Catatan Atas Laporan Keuangan}

Catatan atas laporan keuangan hanrs disajikan secara sistematis. Setiap pos dalam neraca laporan laba rugi dan laporan arus kas harus berkaitan dengan informasi yang terdapat catatan atas laporan keuangan. Catatan atas laporan keuangan mengungkapkan (IAI, 2004) :

1) Informasi tentang dasar penyusunan laporan keuangan dan kebijakan akuntansi yang dipilih dan diterapkan terhadap peristiwa dan transaksi yang penting.

2) Informasi yang diwajibkan dalam Pernyataan Standar Akuntansi Keuangan tetapi tidak disajikan di neraca, laporan laba rugi, laporan arus kas, dan laporan perubahan ekuitas.

3) Informasi tambahan yang tidak disajikan dalam laporan keuangan tetapi diperlukan dalam rangka penyajian secara wajar.

\subsection{Analisis Rasio Keuangan}

Mengadakan analisa hubungan dari berbagai pos dalam suatu laporan keuangan adalah merupakan dasar untuk dapat mungetahui kondisi keuangan dan hasil operasi suatu perusahaan. Dengan menggunakan laporan keuangan yang diperbandingkan, termasuk data tentang perubahan-perubahan yang terjadi dalam jumlah rupiah persentase serta trend nya, penganalisa menyadari bahwa beberapa rasio secara individu akan membantu dalam menganalisa dan menginterpretasikan posisi keuangan suatu perusahaan. Analisis rasio adalah suatu analisa yang menggunakan kondisi dan prestasi dari sebuah perusahaan.

Analisis rasio seperti halnya alat-alat analisa yang lain adalah "future oriented", oleh karena itu penganalisa harus mampu untuk menyesuaikan faktor-faktor di masa yang akan datang yang mungkin akan mempengaruhi posisi keuangan atau hasil operasi perusahaan yang bersangkutan.

Tujuan tiap penganalisis pada umumnya adalah untuk mengetahui tingkat rentabilitas dan likuiditas dari perusahaan yang bersangkutan, oleh karena itu angkaangka rasio pada dasarnya juga dapat digolongkan antara lain :

1. Rasio Likuiditas

2. Rasio Solvabilitas

3. Rasio Rentabilitas

Berdasarkan uraian di atas penulis dapat mendefinisikan bahwa analisa rasio keuangan merupakan perbandingan antara dua/kelompok data laporan keuangan dalam satu periode tertentu, data tersebut bisa antar data dari neraca dan data laporan laba rugi. Tujuannya adalah memberi gambaran kelemahan dan kemampuan finansial perusahaan dari tahun ketahun.

\subsection{Jenis-jenis Rasio Keuangan}

Secara umum, rasio keuangan dapat dikelompokkan menjadi rasio likuiditas, rasio leverage, rasio aktivitas dan rasio profitabilitas (Najmudin, $2011: 86$ ).

1. Rasio Likuiditas

Rasio ini menunjukkan kemampuan perusahaan dalam menyelesaikan kewajiban jangka pendeknya (kurang dari satu tahun). Menurut (Najmudin, 2011: 86), rasio likuiditas dapat dibagi menjadi tiga:

a. Current Ratio (CR) yaitu perbandingan antara aktiva lancar dan hutang lancar

b. Quick Ratio (QR) yaitu perbandingan antara aktiva lancar dikurangi persediaan terhadap hutang lancar.

c. Working Capital to Total Asset (WCTA) yaitu perbandingan antara aktiva lancar dikurangi hutang lancar terhadap jumlah aktiva.

2. Rasio Solvabilitas/Leverage 
Rasio ini menunjukkan kemampuan perusahaan untuk memenuhi kewajiban jangka panjangnya. Rasio ini dapat diproksikan dengan (Najmudin,2011 : 86):

a. Debt Ratio (DR) yaitu perbandingan antara total hutang dengan total aset

b. Debt to Equity Ratio (DER) yaitu perbandingan antara jumlah hutang lancar dan hutang jangka panjang terhadap modal sendiri

c. Long Term Debt to Equity Ratio (LTDER) yaitu perbandingan antara hutang jangka panjang dengan modal sendiri.

d. Times Interest Earned (TIE) yaitu perbandingan antara pendapatan sebelum pajak (earning before tax, selanjutnya disebut EBIT) terhadap bunga hutang jangka panjang.

e. Current Liability to Inventory (CLI) yaitu perbandingan antara hutang lancar terhadap persediaan.

f. Operating Income to Total Liability (OITL) yaitu perbandingan antara laba operasi sebelum bunga dan pajak (hasil pengurangan dari penjualan bersih dikurangi harga pokok penjualan dan biaya operasi) terhadap total hutang.

3. Rasio Aktivitas

Rasio ini menunjukkan kemampuan serta efisiensi perusahaan dalam memanfaatkan aktiva yang dimilikinya atau perputaran (turnover) dari aktiva-aktiva (Najmudin, 2011 : 87). Rasio aktivitas dapat diproksikan dengan:

a. Total Asset Turnover (TAT) yaitu perbandingan antara penjualan bersih dengan jumlah aktiva

b. Inventory Turnover (IT) yaitu perbandingan antara harga pokok penjualan dengan persediaan rata-rata

c. Average Collection Period (ACP) yaitu perbandingan antara piutang rata-rata dikalikan 360 dibanding dengan penjualan kredit.

d. Working Capital Turnover (WCT) yaitu perbandingan antara penjualan bersih terhadap modal kerja.

4. Rasio Profitabilitas

Rasio profitabilitas/rentabilitas digunakan untuk mengukur efisiensi suatu perusahaan dalam menggunakan aktivanya, efisiensi ini dikaitkan dengan penjualan yang berhasil diciptakan (Najmudin, 2011 : 88). Rasio profitabilitas dapat diproksikan dengan:

a. Net Profit Margin (NPM) yaitu perbandingan antara laba bersih setelah pajak (NIAT) terhadap total penjualannya.

b. Gross Profit Margin (GPM) yaitu perbandingan antara laba kotor terhadap penjualan bersih.

c. Return on Asset (ROA) yaitu perbandingan antara laba setelah pajak dengan jumlah aktiva.

d. Return on Equity (ROE) yaitu perbandingan antara laba setelah pajak terhadap modal sendiri.

Dalam penelitian ini jenis rasio keuangan yang digunakan adalah :

1. Rasio Likuiditas

Rasio likuiditas yang digunakan dalam penelitian ini adalah Rasio Lancar atau Current Ratio (CR). Current Ratio (CR) merupakan salah satu ratio financial yang sering digunakan. Tingkat Current Ratio (CR) dapat ditentukan dengan jalan membandingkan antara Current Asset dengan Current Liabilities.

Rasio Lancar $=\frac{\text { Aktiva Lancar }}{\text { Hutang Lancar }} \times 100 \%$

Tahun 2009 :

1. Current Ratio $159,72 \%$ : Setiap hutang lancar Rp 1,00 dijamin oleh aktiva lancar Rp 1,59

2. Cash Ratio $79,77 \%$ : Setiap hutang lancar Rp 1,00 dijamin oleh Quick asset Rp 0,80

3. Quick Ratio 145,24\% : Setiap hutang lancar Rp 1,00 dijamin oleh kas dan efek Rp 1,45

4. Working Capital 19,64 \% : Selisih aktiva lancar di atas hutang lancar adalah Rp 19 Tahun 2010 :

a. Current Ratio 77,11\% : Setiap hutang lancar Rp 1,00 dijamin oleh aktiva lancar $\operatorname{Rp} 7,7$

b. Cash Ratio 30,00 \% : Setiap hutang lancar Rp 1,00 dijamin oleh quick asset $\mathrm{Rp} \quad 0,30$

c. Quick Ratio 70,73\% : Setiap hutang lancar Rp 1,00 dijamin oleh kas dan efek Rp 0,71

d. Working Capital $-4,24 \%$ : Selisih aktiva lancar di atas hutang lancar adalah Rp -4, Tahun 2011 :

1) Current Ratio $113,62 \%$ : Setiap hutang lancar Rp 1,00 dijamin oleh aktiva lancar Rp 1,13 
2) Cash Ratio $41,63 \%$ : Setiap hutang lancar Rp 1,00 dijamin oleh quick asset $\operatorname{Rp} 0,41$

3) Quick Ratio $85,00 \%$ : Setiap hutang lancar Rp 1,00 dijamin oleh kas dan efek Rp 0,85

4) Working Capital 1,95\% : Selisih aktiva lancar di atas hutang lancar adalah Rp 1,95

Berdasarkan hasil perhitungan rasio di atas dapat dilihat bahwa kondisi perusahaan dalam keadaan likuid. Artinya, perusahaan mampu memenuhi kewajiban jangka pendeknya dengan menggunakan asset lancar yang ada. Kondisi tersebut juga menunjukkan adanya penurunan rasio likuiditas pada tahun 2010 dan 2011 dibandingkan dengan tahun 2009.

\subsection{Pengertian Analisis Laporan Keuangan}

Menurut Najmudin (2011:78) pengertian analisis laporan keuangan adalah sebagai berikut, "analisis laporan keuangan terdiri dari penelaahan atau mempelajari daripada hubungan dan tendensi atau kecenderungan (trend) untuk menentukan posisi keuangan dan hasil operasi serta perkembangan perusahaan yang bersangkutan".

Berdasarkan penjelasan tersebut, dapat disimpulkan bahwa analisis laporan keuangan merupakan porses untuk mempelajari data-data keuangan agar dapat dipahami dengan mudah untuk mengetahui posisi keuangan, hasil operasi dan perkembangan suatu perusahaan dengan cara mempelajari hubungan data keuangan serta kecenderungannya terdapat dalam suatu laporan keuangan, sehingga analisis laporan keuangan dapat dijadikan sebagai dasar dalam pengambilan keputusan bagi pihak-pihak yang berkepentingan.

\subsubsection{Tujuan Analisis Laporan Keuangan} Menurut Najmudin (2011 : 78), kegunaan analisis laporan keuangan ini dapat dikemukakan sebagai berikut:

1. Dapat memberikan informasi yang lebih luas, lebih dalam daripada yang terdapat dari laporan keuangan biasa.

2. Dapat menggali informasi yang tidak tampak secara kasat mata (explicit)

dari suatu laporan keuangan atau yang brada di balik laporan keuangan (implicit).

3. Dapat mengetahui kesalahan yang terkandung dalam laporan keuangan.
4. Dapat membongkar hal-hal yang bersifat tidak konsisten dalam hubungannya

dengan suatu laporan keuangan baik dikaitkan dengan komponen intern. laporan keuangan maupun kaitannya dengan informasi yang diperoleh dari luar perusahaan.

5) Mengetahui sifat-sifrt hubungan yang akhirnya dapat melahirkan modalmodel dan teori-teori yang terdapat di lapangan seperti untuk prediksi, peningkatan (rating).

6. Dapat memberikan informasi yang diinginkan oleh para pengambil keputusan. Dengan perkataan lain yang dimaksudkan dari suatu laporan keuangan merupakan tujuan analisis laporan keuangan juga antara lain:

a. Dapat menilai prestasi perusahaan

b. Dapat memproyeksi

laporanperusahaan

c. Dapat menilai kondisi keuangan masa lalu dan masa sekarang dari aspek waktu tertentu:

1) Posisi keuangan (Asset, Neraca dan Modal)

2) Hasil Usaha Perusahaan (Hasil atau Biaya)

3) Likuiditas

4) Solvabilitas

5) Aktivitas

6) Rentabilitas atau Profitabilitas

7) Indikator Pasar Modal

d. Menilai perkembangan dari waktu ke waktu

e. Menilai komposisi struktur keuangan, arus dana

7. Dapat menentukan peringkat (rating) perusahaan menurut kriteria tertentu yang sudah dikenal dalam dunia bisnis.

8. Dapat membandingkan situasi perusahaan dengan perusahaan lain dengan periode sebelumnya atau dengan standar industri normal atau standar ideal.

\subsection{Pengertian Tingkat Kesehatan Perusahaan}

Tingkat kesehatan perusahaan adalah mempertahankan kelangsungan hidup dan kelancaran proses industrinya serta menjadi tolak ukur untuk memantau sejauh mana perusahaan mampu menjaga agar kelancaran operasi perusahaan tidak terganggu (Riyanto, 1993 : 25). Manajer juga harus dapat memahami kondisi keuangan perusahaannya karena pada dasarnya kondisi keuangan mempengaruhi 
kelangsungan hidup perusahaan secara keseluruhan.

Mengetahui tingkat kesehatan perusahaan dan kondisi keuangan perusahaan manajer dapat mengambil keputusan untuk menyusun rencana yang lebih baik dan dapat mengevaluasi apakah kebijakan yang selama ini ditempuh sudah tepat atau belum. Mempertahankan kelancaran proses industrinya perusahaan perlu menganalisis dan menginterpretasikan laporan keuangannya. Perusahaan juga perlu memperhatikan efisiensi operasinya, karena hal tersebut dapat meningkatkan rentabilitas yang mencerminkan kemampuan perusahaan dalam menghasilkan laba. Apabila suatu perusahaan mampu membayar kewajiban jangka pendeknya pada saat jatuh tempo, maka perusahaan tersebut dikatakan mempunyai likuiditas yang baik. Selain itu, solvabilitas juga merupakan faktor penting karena solvabilitas menunjukkan kemampuan perusahaan dalam memenuhi kewajiban jangka panjang maupun jangka pendeknya, maka jelas bahwa tingkat kesehatan perusahaan perlu diperhatikan demi kelancaran operasi perusahaan (Riyanto, 1993: 30).

\section{ANALISIS SISTEM BERJALAN 3.1 Tinjauan Perusahaan \\ PT. Harapan Guna Sejahtera}

Medan merupakan perusahaan yang bergerak dibidang pembangunan, perdagangan dan jasa.

Pembangunan : General,

Kontraktor, Konstruksi dan Mekanikal Perdagangan : Eksport, Import, Distributor, Real Estate, Grosier Elektronik dan telekomunikasi

Jasa dan Pengadaan : Rent Car, Agen Property, Jasa Penyediaan Tenaga Kerja, Jasa Konsultan, Jasa Securiti dan Jasa Penyewaan dan Pengadaan Kenderaa. Perangkat Keras Komputer, dll. PT. Harapan Guna Sejahtera Medan memiliki tujuan dan sasaran.

Tujuan : Mengembangkan usaha, mengamankan Asset-asset KOKARLIN dan menghindari terjadinya monopoli pekerjaan yang diberikan oleh PT PLN (Persero)

Sasaran : 1. Mengerjakan proyek-proyek di PLN dan di instansi-instansi lainnya.

2. Meningkatkan pendapatan.

3. Meningkatkan mutu pengelolaan.
4. Meningkatkan kwualitas pelayanan.

5. Membangun image dengan menjaga kepercayaan dan amanah yang diberikan mitra kerja.

\section{RANCANGAN SISTEM USULAN \\ 4.1 Prosedur Sistem Usulan}

Dibawah ini merupakan prosedur sistem usulan yang telah dirancang oleh penulis yang meliputi proses-proses sebagai berikut :

1. Proses input data keuangan

Langkah pertama yang harus dilakukan untuk input data adalah input data laporan keuangan, dimana pada proses ini adalah untuk penentuan jumlah aktiva lancar dan jumlah ekuitas (kewajiban) agar tidak terjadi penyimpangan dana.

2. Proses input data aktiva lancar

Kemudian langkah selanjutnya adalah input data aktiva lancar dimana pada proses ini merupakan jumlah dari total aktiva.

3. Proses input data ekuitas (kewajibal., Kemudian proses input data ekuitas (kewajiban), dimana pada proses input data ekuitas akan menunjukkan keseimbangan total aktiva dan total pasiva.

4. Proses pembuatan laporan

Langkah terakhir yang dilakukan adalah membuat laporan, dalam proses pembuatan laporan ini akan dilakukan pembuatan jumlah aktiva, jumlah hutang jangka pendek, dan hutang lancar pada PT. Harapan Guna Sejahtera Medan.

\subsection{Jadwal Implementasi}

Pada dasarnya, Rencana implementasi adalah suatu prosedur atau uraian mengenai tahapan yang akan dilakukan, dan menjelaskan segala sesuatu yang dibutuhkan dalam proses implementasi yang berupa komputerisasi sistem.

Pada proses implementasi ini dibutuhkan jadwal yang berfungsi sebagai panduan atau pedoman terhadap kegiatan serta tahapan yang harus dilakukan di dalam proses perhitungan rasio keuangan Menggunakan VB.Net pada PT. Harapan Guna Sejahtera Medan.

4.5 Implementasi

Program dapat didefenisikan sebagai kumpulan dari instruksi-instruksi atau perintahperintah terperinci yang sudah disiapkan oleh 
komputer sehingga dapat melakukan fungsi sesuai dengan yang telah ditentukan. Berikut ini adalah tampilan program yang telah dirancang dari aplikasi perhitungan rasio likuiditas pada PT Harapan Guna Sejahtera Medan :

\section{a. Tampilan Input}

Tampilan input atau masukan sistem dari perhitungan rasio likuiditas pada PT Harapan Guna Sejahtera Medan :

1. FormLogin

Login merupakan tampilan awal pada saat sistem dijalankan. dimana login untuk masuk ke aplikasi yang ada pada menu utama. Seperti yang terlihat pada gambar IV. 10

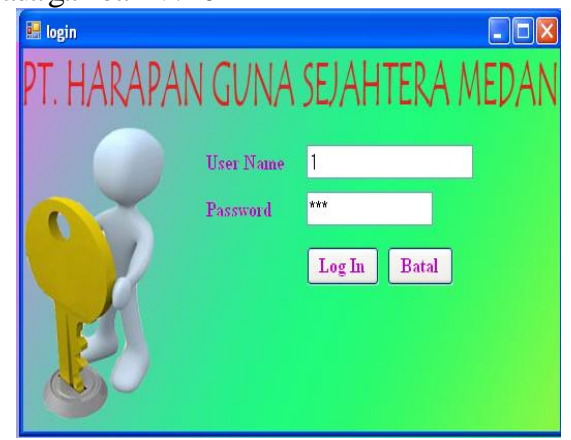

Gambar IV. 10 Form Login

\section{Form Menu Utama}

Menu utama merupakan tampilan awal pada saat sistem dijalankan. dimana pada menu utama terdapat menumenu untuk menginput data-data dan membuat laporan, seperti yang terlihat pada gambar IV. 11

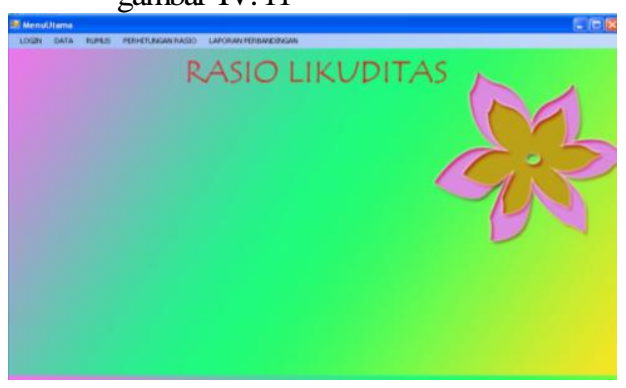

\section{Gambar IV.11 Form Utama}

\section{Form Data Keuangan}

Form data Keuangan merupakan form untuk pengisian data baik menambah, mengubah, menghapus data. Dimana data yang diinputkan adalah tahun kemudian melakukan proses Simpan seperti tampak pada gambar IV.12

1. Gambar Aktiva Lancar

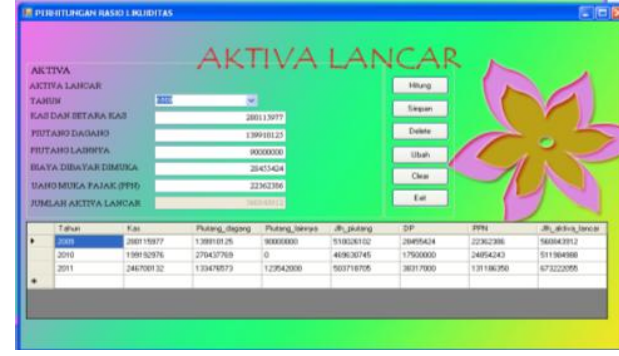

Gambar IV.12 Form Aktiva Lancar

2. Form Kewajiban Jangka Pendek

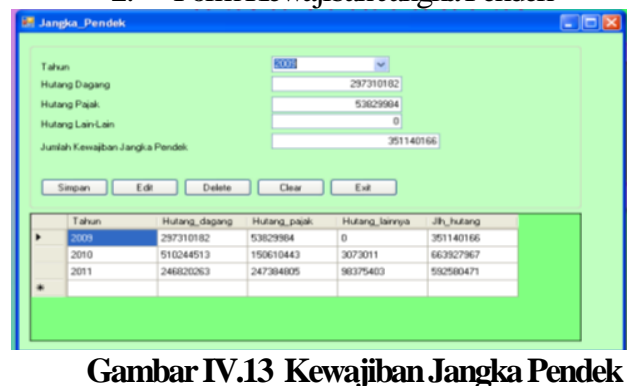

3. Form Aktiva Tetap

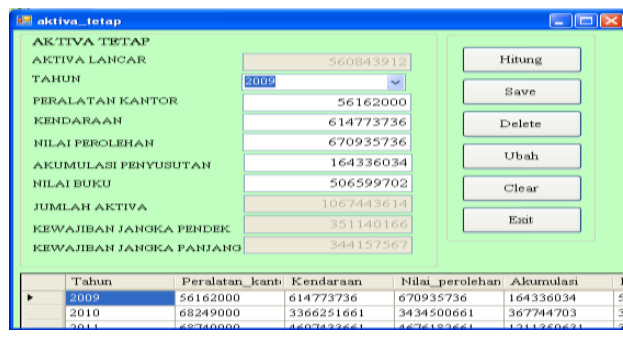

Gambar IV.14 Aktiva Tetap

5. Form Working

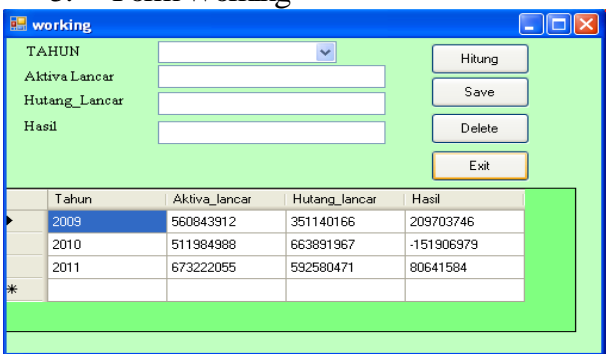

\section{Gambar IV.15 Working}

b. Tampilan Output

Tampilan output atau keluaran sistem dari Aplikasi perhitungan rasio likuiditas pada PT Harapan Guna Sejahtera Medan laporan perhitungan rasio likuiditas adalah sebagai berikut:

1. Laporan Output Perhitungan Rasio Likuiditas

a. Laporan Perhitungan Rasio Likuiditas tahun 2009

Bentuk tampilan output dari laporan data keuangan dapat dilihat pada gambar IV. 16 dibawah ini : 


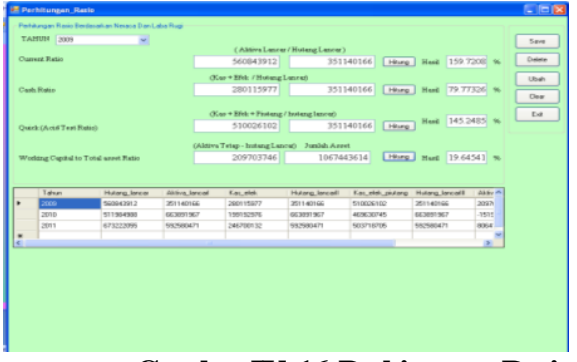

Gambar IV. 16 Perhitungan Rasio Likuiditas pada tahun 2009

b. Laporan Perhitungan Rasio Likuiditas tahun 2010

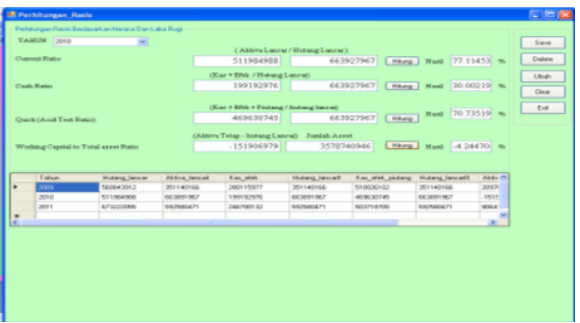

Gambar IV.17 Perhitungan Rasio Likuiditas pada tahun 2010

c. Laporan Perhitungan Rasio Likuiditas tahun 2011

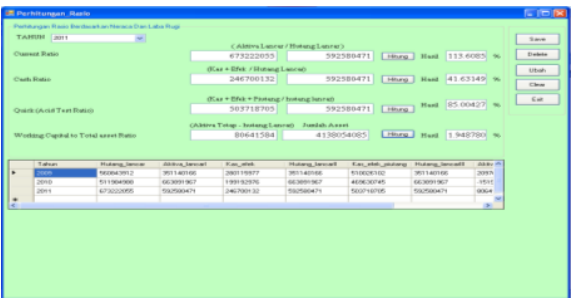

Gambar IV.18 Perhitungan Rasio Likuiditas pada tahun 2011

\section{KESIMPULAN DAN SARAN}

\subsection{Kesimpulan}

Aplikasi Perhitungan rasio

likuiditas adalah suatu program aplikasi yang dapat digunakan untuk proses penyimpanan data keuangan dan data-data pengolahan transaksi lainnya. Dengan memperhatikan hal-hal yang diuraikan dalam laporan penelitian ini maka dapat diambil kesimpulan sebagai berikut :

1. Rasio keuangan perusahaan belum dapat dikatakan baik di karenakan mulai tahun 2009 sampai tahun 2011 masih berada di nilai batas wajar walau pun ada tingkat kenaikan dan penurunan rasio keuangan dari tahun 2009 sampai tahun 2011.

2. Perusahaan selalu menggunakan analisis laporan keuangan di dalam menilai tingkat kesehatan perusahaan dan didalam melanjutkan usaha perusahaan.

3. Dengan adanya Aplikasi Perhitungan rasio likuiditas dapat menilai tingkat kesehatan perusahaan pada setiap tahunnya.

\subsection{Saran}

Berdasarkan kesimpulan yang telah diuraikan diatas maka didapat saran- saran yang diharapkan dapat menjadi masukan dan dorongan yang bermanfaat serta berguna bagi pengembangan usaha perusahaan untuk kedepannya, adapun saran-saran tersebut sebagai berikut :

1. Perusahaan harus melakukan evaluasi guna menjaga nilai analisis rasio keuangan tetap berada pada batas nilai wajar (2:1) $200 \%$ berbanding $100 \%$ dengan cara menaikkan jumlah current asset.

2. Seluruh perusahaan harus menjadikan analisis laporan keuangan (rasio keuangan) sebagai alat ukur didalam menilai tingkat kesehatan perusahaan dan menilai tingkat kelanjutan usaha perusahaan dengan demikian nilai rasio keuangan dapat menunjukkan berjalan tidaknya usaha perusahaan dan menunjukkan sehat atau tidaknya perusahaan terutama hal ini ditunjukkan oleh rasio likuiditas yang menilai penuh tingkat likuiditas perusahaan.

\section{DAFTAR PUSTAKA}

[1] Satradipoera, Komarudin, Strategi Manajemen Bisnis Perbankan Konsep dan Implementasi Untuk Bersaing, Edisi Pertama. Kapana Sigma,Bandung.2004

[2] Munawir, S. Analisa Laporan Keuangan. Liberty, Yogyakarta.2004

[3] Najmudin, Manajemen Keuangan Dan Aktualisasi Syariyyah Modern, Andi Publisher, Yogyakarta.2011. 